\title{
MISSIONS AMONG THE MOSLEMS OF JAVA*
}

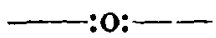

JAVA has an area of 130,544 square kilometres (four times as large as the Netherlands), and with its population of thirty millions is the most important of all Dutch possessions. On the west of the Island live the Soendanese, in the centre the real Javanese, and in the east an immigrant race from the neighbouring Madoera Islands.

Each of these races, however closely rclated, has its own language and history. It is evident, both from the legends of the people and the archæological remains and inscriptions, that even at the beginning of the Christian era the inhabitants of Java had attained to a considerable degree of civilisation.

About the year 100 A.D. the influence of India began to be felt in Java, first that of Hinduism, and later of Buddhism. At the beginning of the fifteenth century Islam reached the coast, also by way of India, and by the close of the century Java had become practically Moslem.

It has been proposed to call the religion of Java "Javanism," because it did not seem correct to consider the population Moslems in the true sense of the word. Since acknowledging, however, that Islam everywhere admits pagan elements in its system, one cannot help counting its millions as Moslems, in spite of the animistic, Hindu and Buddhist elements that persist in the life of the people. We must add that Islam is penetrating deeper into the life of its followers. The many pilgrims returning from Mecca (in 1911, 25,260 from the Dutch East Indies) are not, as has sometimes been alleged, all Moslem missionaries, nevertheless they strengthen Islam by their political aspirations.

* [Translated and abbreviated from the Dutch.-ED.] 
The Dutch Government is strictly neutral as regards all religious movements in Islam, but is energetically opposed to political movements.

In the religious life of the Javanese, the so-called ngelmoe plays an important part. The word is a corruption of the Arabic word 'ilm, and is considered in Java as synonymous with magic.

The Javanese trust implicitly in the effect of ngelmoe, and many of them pursue the knowledge of it all their lives. It is imparted by the goeroe to his moerids or disciples. The disciple, however, is not freed from his master after he has learned. A magical bond unites them perpetually.

Frequent disputes on points of theology take place between these goeroes, and the one who is overcome becomes the disciple of the victor in the dispute. To separate a Javanese from his goeroe is an impossibility. Here also we notice infuences from India. In their disputes logic holds a small place, but etymology and curious coincidences are considered arguments. In these public disputes, the one who can argue the longest is generally the one who wins.

Missions in Java began by voluntary workers, and not by qualified missionaries sent out by regular societies. In the charter of the United Dutch East India Company, mention was made concerning the spread of the reformed religion. Nevertheless, missions were not carried on because of Moslem fanaticism. The results were limited to some feeble efforts at Batavia, and the founding of a Christian Church by one of the Government officials, Cornelis Chasteleyn, who died in 1714.

The Dutch Missionary Society (Nederlandsch Zendelinggenootschap), founded in 1797, sent out three missionaries to Java in 1814, one of whom, Briiclner, translated the New Testament, but the Government forbade its circulation. The other missionaries were sent to the Molukka Islands, and, while they were waiting, J. Kam founded a christian society at Soerabaia, known afterwards as "The Circle of the Pious."

Among those who belonged to it was a German clockmaker, called Embde. This man had heard that 
perpetual summer reigned in Java, and in his literal Bible interpretation of Genesis viii. 22, he could not believe it. He, therefore, had gone out to Java to investigate ; nor did he lose his faith in God's Word, but began to evangelise! His methods were not always very rational. He had no idea of the psychology of the Javanese. The language used in his tracts for them was strange, even for the very few who were able to read. The results of his work were limited to the servant class among Europeans, half caste women and their children.

Among the converts was a man named C. Coolen, the son of a Russian father and a Javanese mother. He was more of a Javanese than a European, both in appearance, ideals and sympathies. This became very evident when he settled in the vicinity of Soerabaia in 1828, and began the cultivation of some waste land and attempted to evangelise his workmen.

Of imposing personality, and mingling the dress and bearing of the European with that of the native, his authority and financial position enabled him to exercise a strong influence on those around him; this was due also to his knowledge and tact, his stern uprightness and unselfishness of conduct, and his thorough knowledge of the colloquial. He soon became the owner of a considerable plantation, was the leader of a Javanese orchestra, as well as in the popular sports of the Javanese. He shared with the people in all their national tastes, and was, therefore, peculiarly qualified to hold the attention of a native audience. When Sunday came he would conduct the services dressed in clerical garb. The whole congregation arose when he ontered, and the church full of people chanted the creed to a Javanese melody. After prayer he would preach sermons, generally from the Old Testament, with interesting practical, although peculiar, exegesis. At the close of the service the whole congregation used to follow him to his house, and there a sort of private theatrical, wajang, was shown, Coolen using this method to draw parallels between the heroes of Javanese folk-lore and those of Holy Writ. This exhibition often lasted the whole day, and the congregation was entertained with refreshments, etc. 
It did not take long before the whole community began to speak about this leader of Ngara, who proclaimed a new ngelmoe. They began to teach each other the fundamentals of the new religion, namely, the Ten Commandments, the Lord's Prayer, and the Apostles' Creed.

There is no doubt that Coolen himself was not unconscious of the fact that the people interpreted his teaching in this Javanese way, nor, perhaps, of the dangers latent in these methods of evangelism. His entire work was of a temporary character. He never thought of forming churches, although a social tie bound the people together to his estate. There was no use of the Sacraments. At first he included them, afterwards he opposed them. No evangelisation was carried out into the neighbouring districts. Coolen knew too well that the Javanese themselves would spread his doctrine because of their fondness for religious discussion. His greatest fault, however, was in the moral sphere. Here he allowed himself liberties contrary to the Gospel. His wife having refused to follow him inland from the coast, he lived with more than one Javanese native woman. It is typical of the oriental mind that his influence on this account did not decrease, his other good qualities overbalancing this lapse in public opinion.

It is clear that Coolen, not only in his morals but in his entire conception of evangelisation, departed greatly from the opinions held by "The Circle of the Pious," to whom he owed his conversion. Among them there was a hearty, although narrow, type of vital Christianity; among them the Gospel was not liberated from its European dress. There were no concessions to the Javanese mind. The converted Javanese were expected to assume European garments, to cut their hair in European style, etc. Coolen made the Gospel so Javanese, that in doing so he excluded some of its fundamental elements. Embde and his followers erred in the other extreme, and made no distinction between form and substance in their preaching.

Conflict between these two methods did not at first arise, because of the long distance between Soerabaia 
and Ngara, but it was inevitable. At Wijoeng, a little village near Soerabaia, lived a Moslem Sheikh named Paq-Dasimah, who ever since he had received a translation of the Gospel had meditated on the question, How God could have a son (Mark i. 1). Some of the followers of Coolen gave him fragments of the Creed, which he tried to combine with the Gospel story. In this way he and his followers came in contact with Coolen's Mission. It is remarkable that when Coolen referred him to Embde, who lived so much nearer to him, his advice was not accepted. He much preferred the instructions of a half-native. Providentially, he met one of the servants of Embde at a village market, and when these brethren-in-Christ heard of the group at Wijoeng, they received them with enthusiasm. Questions of race or caste did not perplex them. Paq-Dasimah and his followers were invited by Embde to sit at his own table, and as their knowledge of the Gospel was very considerable, the Dutch workers were surprised that these Christians had not been baptized.

After some hesitation, the ministers of the State Church at Soerabaia baptized thirty-five Javanese publicly on December 12th, 1843. On the 25th December, 1844, there was a second baptismal service of fifty-seven Javanese.

Coolen was not pleased with these events, and although he was persuaded afterwards of the importance of baptism, he was much offended when certain of the baptised Christians in their European dress appeared at his services. Some of his disciples began work in neighbouring districts, and his teaching spread widely, especially through his strong personality and his accommodation to native thought and life in his preaching.

A missionary once told me that if the Dutch Government had taken a more friendly attitude instead of being afraid of fanaticism, in his opinion the whole of the three Residences-Kediri, Soerabaia, and Pasoeroean-with a population of seven million souls, would have been Christianised ! I cannot vouch for the accuracy of this statement, but it is certain that a movement towards Christianity had begun under the leadership of one who 
was more than half Javanese, and was being propagated by the Javanese themselves.

The existence of Javanese Christians finally overcame the prejudice of the Government, and they permitted missionaries to reside in Java. In $1848 \mathrm{E}$. Jellesma came from the Island of Ceram, where he had been sent in 1843 by the Nederlandsch Zendelinggenootschap.

When Jellesma applied to be sent as a missionary, his timidity was one of the reasons urged against him, but this timidity of manner and great gentleness proved to be the very cause of his popularity among the Javanese. The boldness, loudness and self-assertion of the average European do not appeal to the Javanese. Of Jellesma they undoubtedly said among themselves, "Here at last we have a respectable Hollander."

Nor was he without intellectual gifts and spiritual power, as his work afterwards indicated.

Stationed between the fields of Embde and Coolen, his task was not an easy one. He obtained permission, however, from the Government, to go into the interior, and in 18.51 he established a Christian village by building bamboo houses at Madja-warna. Jellesma understood the importance of this method. It has often been asserted that missions should seek for the centres of populations and trade. Our experience teaches the contrary. The natives who live in these trade centres are no longer real natives. They have become Europeanised, and, for a large part, denationalised. If we desire to establish a national self-propagating church, then we must seek the native where he is still native and out of touch with so-called European culture.

Jellesma understood this thoroughly. He knew how to work in harmony with native leaders, allowing them to follow their own methods to a large extent, and to remain Javanese. Later, a training school was opened. Men were trained who understood the Gospel and were of great service to the mission, but propagandists of the type found in the early days are rare. It is questionable whether this course of events could have been avoided. In proportion as the Javanese understands the Gospel better, he separates himself from the spiritual life and 
thought of his people. But European leaders must continue to learn from their pupils and help them to build up a Christian theology in Javanese thought, being on their guard lest they translate European ideas into Javanese words merely, rather than into Javanese thought. Their logic is different from ours. Arguments which appeal to us have no strength with them. Our theology is too largely determined by the controversies through which it has come. On the mission field the whole position calls for different lines of action, and will also come to its own. Only when we bear this in mind will the Javanese Christians be fitted to evangelise their own people.

In these remarks on the education and training of native preachers we have anticipated the history of missions in Java.

A crisis followed the earliest effort of missions, of which we have spoken. The number of workers sent out was comparatively large, but the influence in the Netherlands of another theology, altogether radical in its tendency, was detrimental to the spiritual life of the missionaries. Others had to return for reasons of health, and the result was that the number of missionaries in East Java was much smaller than it should have been for the task in hand.

The rumour of Coolen's work spread far beyond his own settlement. In the residencies of Kediri, Soerabaia and Pasoeroean, and even in the residencey of Madioen to the west, Christian groups were formed.

The Netherlands Society sent out its missionaries, and they succeeded in winning the confidence of the people. They also made a careful study of the intellectual and spiritual condition of the people, and established a most valuable periodical with this special aim, entitled " Mededeelingen van wege het N. Z. G.", which has now reached its fifty-eighth annual volume.

The method of work followed, which calls for special attention, is that of the Christian dessa or community settlement. The opening of these settlements was not due primarily to the missionaries. The initiative came from the people themselves. 
At present the missions are generally agreed that the progress and strength of native Christian life is furthered by this method more than by any other. The communion of faith strengthens the social bond, and the social bond helps forward the spiritual interest.

The fear has been expressed lest in this way the Christians should separate themselves too much from their Moslem neighbours, but this fear is groundless, as the population is so dense and there does not exist a single dessa exclusively composed of Christian inhabitants. Moslems live with the Christians, although under certain conditions, and intercourse between them and the Moslem population is constant. The spiritual and moral condition of these congregations is generally good. The greatest difficulty is the lack of independence on the part of the native, but it is most encouraging that apostacy back to Islam very seldom occurs among the converts.

I may here mention the peculiar method of exercising discipline. The Sacrament of the Lord's Supper is only given when the congregation ask for it, which occurs with considerable regularity. When the request is made the missionary has a severe task before him. He has a personal interview with each of the Church members, with the result that those who are not judged fit to come to the Table of the Lord remain away of their own accord. To be forbidden the Sacrament by a missionary would not be considered as discipline, but as a sufficient excuse for absence !

Our chief difficulty remains that the Javanese Christian Church shows too little real missionary spirit. However, in the year 1913 eighty-two Moslems were admitted into church fellowship, and in the previous year one hundred and sixty-one.

In spite of the criticisms which we have passed on the methods of Embde and Coolen, one cannot deny that in later years European influence was often too strong in missionary effort, and too little room was left for that which was typically Javanese, and, therefore, the initiative of the native church was not developed. It is naturally difficult to find the golden medium.

Without European direction and control at the outset 
(as we see in what follows), Christianity is in danger of becoming simply a new element in Javanese syncretism. More and more the conviction is gaining ground, however, among the missionaries, that in all propagandism among Moslems they must keep themselves in the background, and in the words of that Nestor among our missionaries, J. Kryut, " Be as the mainspring of a watch, invisible but indispensable."

Among the Europeans who engaged independenly in missionary work we must mention Mr. F. L. Anthing, a high native official, who died in 1883 at the age of sixtythree. From his youth he was a decided Christian, and, beginning at Semarang in 1863 , he did considerable work for the spread of the Gospel among the native population by supporting helpers trained by himself. At one time their number was fifty-seven. His work was fruitful in results.

In the central province of Java the work of a hermit, named Toenggoel-Woeloeng, deserves special attention. $\mathrm{He}$ was a typical Javanese goeroe. $\mathrm{He}$ came in contact with native Christians, and having found one day a copy of the Ten Commandments under his mat, he believed that it was a supernatural call. Later he heard a voice from heaven advising him to go to Madja-pahit and hear the truth. Here he found Jellesma and was baptised as a Christian. Later he preached the Gospel, but not under missionary supervision, establishing a dessa in the Residency of Djapara. The syncretism of his teaching, however, alienated the sympathy of the missionaries. When he died in 1885 he had over one thousand disciples who were proud of their Christian name, but whose Christianity was more or less of the type of their goeroe.

The results of the work of another native leader, Sadrach, were much greater. Before his conversion he followed the teaching of various Mohammedan goeroes. He first learned of Christianity through the missionaries, but afterwards came under the influence of ToenggoelWoeloeng, travelled through Java, especially on the east coast, and was baptised at Batavia in 1867. Two years later he established himself at Poerworedjo and began the work of evangelisation. By his education 
and strong personality he became a leader of all those who now call themselves "Kristen djawa" (Javanese Christians), in contrast to those converts who followed the European missionaries and bore the name of "Kristen blanda" (Holland Christians). These latter numbered, at that time, about six thousand.*

The preaching of Sadrach undoubtedly contained more Christian elements than that of his predecessor, but in some respects his teaching also, and especially his desire for the honour of a goeroe toward his disciples, does not seem compatible with true Christianity. The accusations made that he receives money from his converts and that he is a rich man, are untrue, but his attitude shows undoubtedly the lack of thorough Christian training.

Since 1862 the Reformed Church Mission (Gereformeerde Zend. Ver.) has worked in this district. Their missionaries tried to influence Sadrach and his circle, but the results were not satisfactory. The attempts made to separate the followers of Sadrach from their goeroe were vain. Sadrach turned from the missionaries to a circle of Irvingites at Batavia, and was appointed Apostle by them. The relations between him and the Reformed Church Mission were, therefore, broken.

It is impossible to fortell the future. At present the influence of Sadrach is still dominant, but he is an old man. Among his followers there are many from whom much good may be expected. All of them value most highly the name " Christian." 'This fact, and the clear insight now obtaining in mission circles regarding these native movements, promises much for the future.

If their expectations are not realised it will not be because of lack of energy on the part of the Reformed Churches. These churches lay great emphasis on the autonomy of the local congregation. Some of them since 1834 , but the majority since 1886 , are independent of the old State Church. They number, in the Netherlands, about five hundred thousand members. $f$

* The statistics now given of 24,000 native Christians in Java do not include the followers of Sadrach and Toenggoel-Woeloeng.

$\dagger$ The Government for a long time opposed the work among Moslems, but the Churches of Holland did not cease their efforts. 
The various mission stations in Java are fairly well distributed. Although most of the Dutch societies are labouring exclusively on this island, there has been comity in the division of territory. On the other hand, the location of the various stations has not been altogether systematic, nor have the societies concentrated their efforts where the results were the greatest and the prospects most alluring.

Apart from the followers of Sadrach, no other mass movement towards Christianity has taken place. We cannot tell, however, how soon this may happen again, and the part of wisdom is to follow a policy of distribution of forces, rather than of concentration, so that we may reap the results of any favourable movement anywhere.

At present, all the missions in Java are decidedly evangelistic in character. The native churches are supervised by the Javanese, or by European assistants not ordained. Every year scores, and sometimes hundreds of Moslems are added to the church. Every congregation has its own pastor or teacher, who is at the same time a director of the school. There are five schools for the training of mission teachers. Those who show special ability receive a two years' course in theology preparatory to future ordination.

It seems to me that some of the societies have spent too much of their strength in sending out missionaries where more attention should have been given to the training of native workers.

At present, seven societies are at work. Two have already been mentioned. In 1851 the Dutch Baptist Missionary Society (Doopsgezinde) began work at Djapara. About the same time a Christian lady, residing in Java, began work at Salatiga, assisted by some helpers granted by the missionaries. When she returncd to the Netherlands in 1857 she left behind her fifty baptised converts. In 1884 the Salatiga Mission was organised on a faith basis and continued her work. The west coast of Java is the field of the Ned. Zendingsvereeniging, founded in 1858, and they have been successful enough in this difficult field to establish a number of small churches among the Soendanese. Recently they have begun work among the agricultural population inland. 
When Mr. Anthing died in 1883, the nine congregations, with about seven hundred and fifty members under his charge, were transferred to the last-named society. The Java-Comité has its work in the extreme East of Java since 1879.

In 1905 the Board of Foreign Missions of the Methodist Episcopal Church began work on the island. It is unfortunate, however, that this society did not consult the other societies before beginning its work, for which undoubtedly there is room enough in Java.*

To complete the list of societies and agencies $\mathrm{I}$. must mention the Salvation Army, which works among IndoEuropeans, and also the seminary established at Depok, near Batavia, in 1873, for the training of native preachers.

Concerning the prospects of mission work in Java, nothing can be said with certainty. It is possible that there may be movements towards Christianity in the near future, and that the missions may be able to influence Sadrach's community. At present there are no immediate signs of this, however, but there is not the least reason for discouragement. The opportunities are greater than ever. Java also is feeling the influence of the intellectual movements that are sweeping over the East. Not only the higher classes, but the middle classes, are seized with a desire to adopt European culture. The Government is trying to meet this demand, although its schools are naturally without religious instruction, and Christian missions are facing this new opportunity. A committee has been formed consisting of representatives of all the societies for the establishment of schools. Nine have already been opened, with a total of four hundred and four pupils, and receive a subsidy from the Government.

Some are afraid that this movement will awaken Moslem opposition and fanaticism, but the chief danger is that the taking over of western civilisation without its assimilation will be detrimental to the national life of the people. In that case, we may only expect a reaction, with the tendency, to use a German proverb, of "Throwing out the baby with the bath-water." In

* See Miss Elizabeth Harper-Brooks' pamphlet, entitled "Java. and its Challenge," and the Dutch criticisms in their magazines. 
other words, the re-action may be anti-Christian as well as anti-European. In view of this danger, the missions encourage education, but urge that it should be of such a character as shall give the Javanese culture suitable for them, and not in conflict with the best characteristics of the people. It is especially urged that the preaching of the Gospel shall be free from European forms and leave room for a real Javanese Christianity.

Another important method undoubtedly would be the increase of Christian hospitals. At present there are five mission hospitals on a large scale, properly staffed, and a number of smaller ones. The provision made by the Government for medical assistance is altogether inadequate. The subsidies given by the Government, therefore, to mission hospitals are large, and are enough to cover three-fourths of all expenses. This certainly is a golden opportunity to establish work which will offer a vivid illustration to the Javanese of the real character of Christianity and its message of mercy. It is unfortunate that so few Christian physicians offer themselves for this task.

Although educational and medical work arc only indirectly evangelistic, they are not, however, in any sense fruitless. In work among Moslems someone has rightly said that "we need a type of self-denial which utterly disregards all visible results."

Meanwhile, missions continue their steady progress in Java. Islam is a world religion which would never have exercised such a great influence were it not for the elements of truth it possesses. These elements have not always been recognised by Christians themselves; I do not say by Christianity. One thing is certain, that when the Mohammedan peoples shall have been brought to Christ, we shall understand something more of that " fulness of the Godhead which dwells in Christ bodily." Our work among them will prepare us to expect in all humility that day of triumph.

Rotterdam.

J. W. Gunning. 